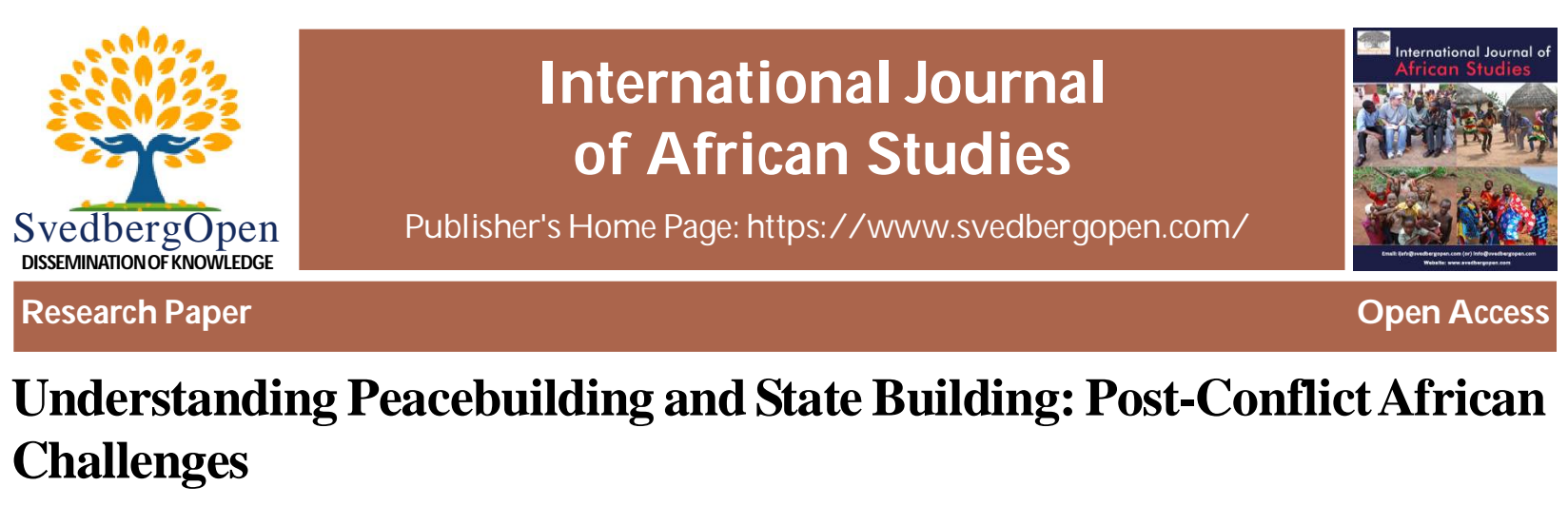

Redie Bereketeab ${ }^{1^{*}}$

${ }^{1}$ Associate Professor of Sociology and Senior Researcher, The Nordic Africa Institute, Uppsala, Sweden.

E-mail: redie.bereketeab@gmail.com

\section{Article Info}

Volume 1, Issue 3, September 2021

Received : 10 April 2021

Accepted : 14 August 2021

Published : 05 September 2021

doi: 10.51483/IJAFRS.1.3.2021.16-30

\begin{abstract}
This paper examines the challenges of post-conflict Peacebuilding and State Building (PBSB) in Africa. The paper's point of departure is a functional and enduring PBSB, basically, deals with the fundamental foundation of societal construction. The paper examines two conceptions. The two are neoliberal and popular progressive. It is the contention of the paper that PBSB is achieved through gradual evolutionary historical process. As gradual historical transformation process, it is contingent on domestic realities, trajectories, socioeconomic, demographic, ethno-political structures, relationship, sociopolitical forces and actor-ship. Unlike neoliberal understanding that focuses on technical and administrative, apolitical and ahistorical, external expertise and knowledge, institutions, top-down, etc. imposition; the alternative model of popular progressive understanding focuses on basics of societal construction. The paper's principal focus is on conceptual and theoretical aspects. It concludes only the popular progressive alternative could achieve sustainable and functional peace, security and development.
\end{abstract}

Keywords: Peacebuilding, State building, Neoliberal, Popular progressive, Post-conflict, Africa

(C) 2021 Redie Bereketeab. This is an open access article under the CC BY license (https://creativecommons.org/licenses/by/4.0/), which permits unrestricted use, distribution, and reproduction in any medium, provided you give appropriate credit to the original author(s) and the source, provide a link to the Creative Commons license, and indicate if changes were made.

\title{
1. Introduction
}

Understand Peacebuilding and State Building (PBSB) in conflict-shattered societies is fraught with controversies. Nevertheless, consensus prevails that conflict-shattered societies suffer from state failure, crisis, fragility, and even collapse. This consensus spurs Western interventionist PBSB. Consequently, blueprints are prepared and bold attempts conducted engineering PBSB. Western powers, driven by geostrategic concerns and fear of spill over of the pathologies afflicting those societies such as terrorism, extremism, fundamentalism and migration to their own societies have actively intervened. The interventions however induce serious controversies. What are the sources and concerns behind the controversies? The paper seeks to interrogate the concerns and controversies. Two central points of departure of the paper are that PBSB by its very nature is domestic and political.

Understanding PBSB requires theoretical and empirical discerning. One of the discernibility entails unpacking the relation between PB and SB. A major part of the general literature purports prevalence of harmony between the two. Arguably, a complementarity characterizes the PBSB relationship (Zaum 2012; Grävingholt et al., 2009). A serious

* Corresponding author:Redie Bereketeab, Associate professor of Sociology and Senior Researcher, The Nordic Africa Institute, Uppsala, Sweden. E-mail: redie.bereketeab@gmail.com 
interrogation however would demonstrate that PB and SB differ in substantive dimensions, as will be demonstrated in this paper. To conduct our inspection we would draw support from two theoretical conceptions as well as empirical exemplifications. The theoretical conceptions are neoliberal and popular progressive.

According to the popular progressive conceptualization, PBSB is essentially domestic. As domestic it is inclusive participatory, involving all stakeholders. An inclusive and participatory process presupposes engaging in protracted negotiations, bargaining, dialogue, compromises, consensus building, etc. of all stakeholders (Bereketeab, 2021). Two points of departure framing the paper are PBSB by its very nature is domestic as well as political. As political, it has to do with power and power allocation. It also conflates top-down and bottom-up strategies. Two notions that underpin functional and enduring PBSB are state emancipation and societal pacification.

The objective of the paper is, by criticizing neoliberal PBSB proffer an alternative one. It seeks to provide a response to the question of how do we understand PB and SB in conflict-shattered societies. The paper consists of six sections. The following section examines PBSB in general. The next section analyses neoliberal PB and SB. A section follows that deals with popular and progressive PB and SB. The next examines state emancipation and societal pacification. The last section provides concluding remarks.

\section{Framing Peacebuilding and State Building}

Two points of departure guide this paper. Firstly, PBSB is domestic by its very nature. As domestic, it involves negotiations, dialogue, bargains, compromises, participation and sharing among national stakeholders. Secondly, it is political by its very nature. As political, is associated with power. Power is about who takes what, how and when and creates winners and losers, which could consequently generate conflict. In addition, PBSB concerns fundamentals of societal construction, in technical parlance nation and state formation. As state and nation formation, it is a protracted, historical and evolutionary process. As such, it is a continuum of past, present and future (Bereketeab, 2020). This domestic and political nature of PBSB cultivates the will to live together, a presupposition for the existence of modern society.

Contrary to claims of some of the general literature, there is discordance between PB and SB.

Yet the most salient finding is that the relationship between peace-building and state building is complicated, contingent, and context-dependent. That is not to say that the specifics of each case prevent generalizations from being drawn. However, peace-building cannot be boiled down to building state institutions. Enhancing state institutional capacity may potentially harm the chances for consolidating peace and vice versa. A number of tensions exist between logic of building states and that of ensuring that war will not recur (Call and Wyeth, 2008).

A closer examination of the harmony-disharmony dichotomy would provide distinct functions and objectives. SB essentially refers to institution building. This conception derives from the presumption that state is a political institution, particularly in its generic abstract context. The chief component institutions of the state are legislative, executive and judiciary. Institutionalization, bureaucratization and routinization of politics presupposes development of political culture (Kamrava 2000; Poggi 1978). Fostering political culture presumably would engender predictability, accountability, transparency, standardization and uniformity. This will cultivate among citizens familiarity, recognition and acceptance. SB as political act addresses allocation of power that creates winners and losers. The phenomenon of winners and losers in turn sparks conflicts that contradict the conception of harmony.

$\mathrm{PB}$, on the other hand, endeavors to bring citizens together through reconciliation, compromises, bridging differences, building confidence, trust and cultivating the will to live together. The central objective of PB is, in addition to halting the fighting and boosting peace between combatants, fostering harmony, peaceful coexistence among various ethnic, religious, cultural and linguistic groups. In other words concerns molding the multiple social fabric of society that would lead to the will to live together.

When we discuss PB, there are related concepts that require distinction, which often create confusion. These are peacebuilding, peace-making, peacekeeping and peace mediation. Peacebuilding could be understood as a summation of peace-making, peacekeeping and peace mediation. Each component element has specific function and objective, the totality of which constitute PB. Peace-making refers to the combatants' willingness and readiness to strike a peace deal, moving toward settlement of armed conflicts; while peace mediation concerns the role of external actors in facilitating conditions for the combatants to strike the deal. Peacekeeping alludes to placement of international armed forces between combatants physically to separate them (Tanabe, 2017). 
Theories of PB abound. The common ones, in the mainstream literature of PB are: (i) structural violence theory, (ii) transformation relationship theory, (iii) protracted social conflict theory, and (iv) relationship building (conflict resolution) theory (Paffenholz 2015). PB is, then, perceived as an 'efforts at national, local, or international levels to consolidate peace in war-torn societies' (Call, 2008a).

Peace is not simply the absence of war (known as negative peace) (Oda 2007; Gawerc 2006). It is about the elimination of cultural, social, political, economic, structural and institutional violence. In this broader conception, positive peacebuilding is multidimensional, multipurpose and concerns non-war-related social issues. These entail provision of services, equitable distribution of resources, development, managing ethnic relations, consensus building, poverty alleviation. The right to education and health, mutual respect and recognition are salient constitutive features of positive PB (Curtis, 2012; Maiese, 2003). Positive peace is a step on from negative peace: that is, if negative peace constitutes the necessary conditions, positive peace constitutes the sufficient conditions for functional and sustainable peace and peacebuilding (Galtung, 1964).

Table 1: Constructed from the General Literature

\begin{tabular}{|c|c|c|}
\hline & State Building & Peacebuilding \\
\hline Neoliberal & $\begin{array}{l}\text { Technical, administrative } \\
\text { Short-term } \\
\text { Top-down } \\
\text { Imposition } \\
\text { External } \\
\quad \text { Knowledge } \\
\quad \text { Institutions } \\
\quad \text { Expertise } \\
\text { Devalue indigenous } \\
\quad \text { Knowledge } \\
\quad \text { Expertise } \\
\text { Institution, authorities } \\
\text { Winners and losers }\end{array}$ & $\begin{array}{l}\text { Deal with combatants } \\
\text { Exclusionary } \\
\text { Top-down, managerial } \\
\text { Reform: DDR, SFR } \\
\text { Temporary, external experts } \\
\text { Alienating } \\
\text { Elitist } \\
\text { Reformist } \\
\text { Formalist } \\
\text { Procedural } \\
\text { Proximate causes }\end{array}$ \\
\hline Popular progressive & $\begin{array}{l}\text { Substantive } \\
\text { Long-term } \\
\text { Bottom-up, top-down } \\
\text { Societal construction } \\
\quad \text { Nation formation } \\
\text { State formation } \\
\text { Institution building } \\
\text { Popular and participatory } \\
\text { Celebrate indigenous } \\
\quad \text { Knowledge } \\
\text { Expertise } \\
\text { Mechanisms } \\
\text { Institutions and authorities }\end{array}$ & $\begin{array}{l}\text { Negotiations, bargains, } \\
\text { dialogue, compromise, } \\
\text { conciliation of all stakeholders } \\
\text { Inclusionary } \\
\text { Domestic } \\
\text { Institutions } \\
\text { Knowledge expertise } \\
\text { Political: distribution of power } \\
\text { Accommodative } \\
\text { Pluralist } \\
\text { Root causes }\end{array}$ \\
\hline
\end{tabular}

\section{Neoliberal Peacebuilding and State Building}

Neoliberal interventionist PBSB in conflict-shattered societies got its breakthrough in early 1990s. The entry point was the UNAgenda for Peace (Sabaratnam, 2011). Two developments underpinned the breakthrough. Firstly, the collapse of state socialism and end of Cold War. Second, the consequent emergence of mono-polar world order that heralded PostCold War and post-Westphalian era. The two developments paved the way for the pre-eminence of the neoliberal ideology. The development, was not only received as the triumph, but also as a testimony of the omnipotence of liberal democracy. Fukuyama (1992) declared end of history, followed by Huntington's (1996) clash of civilizations. Celebrating the triumphalism Dahrendorf (1990), for instance, notes, 
At the end of the century, however, we see the 'unabashed victory of economic and political liberalism'. Moreover, 'the triumph of the West, of the Western idea' marks 'the end of history as such' because there are no fundamental conflicts of concepts of order left. Instead we begin to see the outline of what Fukuyama insists on calling a 'universal homogenous [sic!] state' which consists of 'liberal democracy in the political sphere combined with easy access to VCR and stereos in the economic" (emphasis in original).

Critics of neoliberal interventionist PBSB describe it as ideology, doctrine, social engineering and revolution (Harrison 2010; Mitchell and Fazi 2017). The debate is characterized by lack of clear and consensual understanding as to what constitutes neoliberal PBSB. In its economic context, neoliberalism is associated with economic liberalization, free market, financial and monetary deregulation, anti-inflation measures, macroeconomic stabilization, privatization of stateowned enterprises, control of the budget deficit, reduction in fiscal spending, currency devaluation, less state involvement, etc. - issues commonly connected with the Bretton Woods Institutions (Poku and Whitman 2018; Sandbrook 2007). Neoliberalism is branded as expansionism, interventionism and transgression inducing some to talk about recolonization. Even the highly revered globalization is seen as a trap where the non-West is incorporated in the pyramidal integration world order, Africa laying at the flat bottom of the pyramid.

The elevation of neoliberalism to world hegemonic status is associated with the fall of Keynesianism and an assault on the state. The Keynesian model 'started to crumble in the 1970s under the weight of the so-called neoliberal counterrevolution: an ideological war on Keynesianism (which initially took the form of monetarism) waged by a new generation of die-hard free-market economists, mostly based at the University of Chicago, led by Milton Friedman' (Mitchell and Fazi, 2017). Neoliberals are not against the state per se, 'but they are instead committed to its total transformation so that it may work perfectly for capital and its accumulation' (Lazzarato, 2015). Lazzarato maintains that 'capital has never been liberal; it has always been state capital' (Lazzarato, 2015).

Neoliberalism has become a doctrine, commonly known as liberal peacebuilding, or interventionist humanitarian peacebuilding (Campbell et al., 2011). For critics, it is an imperialist agenda disguised as humanitarianism. Roland Paris (1997), for instance, states that neoliberalism operates, in effect, as 'an enormous experiment in social engineering-an experiment that involves transplanting Western models of social, political, and economic organization into war-shattered states in order to control civil conflicts: in other words, pacification through political and economic liberalization'. He states, elsewhere, that 'peacebuilding agencies transmit such ideas from the core to the periphery of the international system, these agencies are, in effect, involved in an effort to remake parts of the periphery in the image of the core' (Paris 2002). Neoliberal peacebuilding is therefore considered, 'ethically bankrupt, subject to double standards, coercive and conditional, acultural, unconcerned with social welfare, and unfeeling and insensitive towards its subject' (Thiessen 2011).

The IOs are part of the liberal NGO PB enterprise (Paffenholz 2015; Tanabe 2017) that mediate neoliberal ideology through training, capacity building, providing toolbox blueprints and advising local and international practitioners; end product creation of a homogenized global world (Carmody and Owusu, 2018). A post-conflict constitution, drafted by Western experts, contains concepts such as free and fair elections, civil liberties, judicial independence and due process, rule of law, good governance, etc.; which is ratified by a legislative body (Paris 2002). The philosophical assumption of standardized, universalistic values underpin the conception (Tanabe, 2017). The question is does this address the needs of the rural population, for instance, in Africa? Indigenous local institutions and authorities are consciously and systematically undermined. In Sierra Leone, for instance, 'village and chiefdom development committees are no longer accepted as implementing partners because they are generally considered to be "corrupt" (Fanthorpe, 2005). This donor position contravenes the perception of the Sierra Leonean government which was 'chiefdoms are still needed to perform essential local functions, notably the administration of customary land rights, revenue collection, maintenance of law and order' (Fanthorpe, 2005).

Neoliberalism's rise to universal hegemony is facilitated by belief that liberal democracies are inherently more peaceful (Hameiri, 2014) and that peace is a universal human necessity. Therefore, enshrining neoliberalism as a universal order, reaching every corner of the world, is thought to be a noble mission; and it is the solemn responsibility of those who already enjoy to spread it. Underpinning it is the Kantian thesis that liberal democracies are inherently peaceful and do not go to war. The thesis is easily disproved. Western liberal democracies waged war among themselves for hundreds of years (including World War I and World War II). Noting this, Knapp and Footitt (2013) write,

Democracies, democratic peace theory suggest, do not go to war against other democracies. Yet since 1914 democracies have repeatedly found themselves embroiled in wars, great or small, whether to defend their colonial 
possession, their economic and strategic interests, or even their national territory against other power, less democratic and less satisfied with the prevailing international system. Such wars have great potential to subvert democratic values.

In addition, wars waged by Western powers outside their borders such as Somalia, Mali, Afghanistan, Iraq, Libya and Syria, belie the thesis. Therefore 'democracies do not go to war' could be replaced by 'democracies go to war they win' thesis. Reiter and Allan (2002: 10) state, 'We assume that states pick their fight: they start war when the stakes are high enough, and when they are confident they will win'. They further note, 'Our central argument is that democracies win wars because of the offshoots of public consent and leaders' accountability to voters' (2002: 3). The ability to win dictates war rather than principles and democratic ideals. Those who own the means could unleash hell on those they are convinced could easily win. Explicating the development of the modern means of killing that exonerate personal responsibility, the sociologist Zygmunt Bauman, notes,

More, however, than the sheer quantity of tools of destruction, even their technical quality, what matters was the way in which they were deployed. Their formidable effectiveness, relied mostly on the subjection of their use to purely bureaucratic, technical considerations (which made their use all but totally immune to the countervailing pressures, such as they might have been submitted to if the means of violence were controlled by dispersed and uncoordinated agents and deployed in a diffuse way). Violence has been turned into a technique. Like all techniques, it is free from emotions and purely rational. 'It is, in fact, entirely reasonable, if "reason" means instrumental reason, to apply American military force, B-52's, napalm, and all the rest to "communist-dominated" Viet-Nam (clearly an "undesirable object"), as the "operator" to transform it into a "desirable object" (Bauman, 2000).

Paraphrasing Bauman, a drone operator based in the USA, instructed to eliminate "undesirable" Al Shebab, in Somalia, in the process, a simple touch of a button unleashes a deadly bomb and kills innocent bystanders. Modern technology of war deprives us one feature of our humanity, notably emotion. Our common humanity is guided by who wins and dominates.

The neoliberal PB is expected to promote market economy and electoral multiparty democracy. The 1990s were a watershed in neoliberal triumphalism. Aggressive neoliberal discourse and narratives replaced classical liberalism. This discourse accelerated in the wake of 9/11 attacks on the United States (Harrison 2010; Barnett 2006). Richmond (2013) notes: 'Processes of peacebuilding and statebuilding are designed to develop a liberal social contract in contrast to the predatory state that mainstream state formation expects'. Richard Jackson (2018), also notes:

First it [peace-building] has been criticized for operating according to a standardized blueprint which does not take into account the unique historical and cultural settings in which it is applied. As Mac Ginty puts it, 'the liberal peace is operationalized in highly standardized formats that leave little space for alternative approaches', follows 'set templates' in applying reforms, and adopts 'a formulaic path' which often fails to take account of local actors and their preferences and contextual knowledge.

Ostensibly, the construction of war-shattered societies along Western mould, failed to bring lasting peace in Africa. In Angola, for instance, neoliberal inspired PB initiative sparked war, 'the UN oversaw postwar election in 1992 that [instead] provoked one of the former belligerents to resume fighting, in part because there were no institutional mechanisms established to resolve disputes over election' (Paris, 2010). This is partly due to ignoring indigenous institutions and mechanisms of conflict resolution that plunged Angola into bloody civil war (Ngongo, 2012). Concerning South Sudan, also, Wambugu (2019), writes, 'an international engagement that interacted and continued to interact with South Sudan from the premise of an incapable partner, while overlooking the role of the community receiving intervention, perhaps of the greatest tragedies of international liberal peacebuilding approaches'. Others have noted neoliberal peacebuilding in Mozambique did not bring the needed outcome (Sabaratnam, 2011). 'More than two decades of peacebuilding processes in Mozambique have shown that there is no clear cut way to ensure the sustainability of peace in the country' (Reppell et al., 2016).

The wake of Cold War PB was designed along neoliberal democracy and market economy norms and values that side-lined the state and instead non-state actors: IOs, NGOs, CS, oppositions (Newman et al., 2009; Barnett, 2006) were encouraged to play prominent role. The state is not to be trusted (Tom 2017), invariably labeled as predator state, criminal state, patrimonial state, shadow state, etc. (Hyden, 2013; Englebert, 2000; Herbst, 2000; Bratton and de Walle, 1997; Chabal and Daloz, 1999; Bayarat, 1993; Christensen and Laitin, 2019).

For critics neoliberal peacebuilding is formalist, technical and administrative in nature (Chandler, 2013) and draws on pre-determined and imported dispensations. Checklists of reforming security forces, police, intelligence, army, 
demobilization, disarmament and reintegration guide its operations (DDR) (Conteh-Morgan, 2004; Curtis and Dzinesa, 2012; Omach, 2012; Barnett, 2006; Grävingholt et al., 2009; Jackson, 2018). The checklists fail to deal with root causes of conflicts. Funds from IFIs and donor is critical, 'the World Bank started to facilitate state—and peace-building, financing the disarmament, demobilization and reintegration of ex-combatants, as well as mine survey and awareness projects' (Viterbo 2018). The focus on technical solutions neglects the profoundly political nature of conflicts and PB. Paffenholz (2015) notes 'International liberal peacebuilding becomes an inherently conservative undertaking, which seeks managerial solutions to fundamental conflicts over resources and power.' The process is characterized by an overdependence on external experts, which devalues indigenous knowledge, experts and authorities (Thiessen, 2011).

\subsection{Neoliberal State Building}

This section discusses neoliberal interventionist state building (SB). Neoliberal SB is perceived as an ideology rather than science or theory (cf. Harrison, 2010). In this ideologically driven SB, both classical and contemporary theories of SB are markedly absent, not to mention theories and models relevant to developing society realities. Apparently, the foundation of neoliberal interventionist SB derives from other historical, cultural, socioeconomic, political and philosophical societal experiences. In other words, specific ontological and epistemological background.

Interventionist neoliberal SB gained prominence in the wake of Cold War and post-Westphalia. Soon saving the failed state that undergirded interventionism became the leading discourse and policy in the West (Sabaratnam, 2011). The development that underpinned the proliferation of neoliberal interventionist SB could be traced to two factors. Firstly, the collapse of the Soviet Union boosted a sense of liberal democracy triumphalism. It was followed by the emergence of mono-polarity that spurred Western powers to interfere in the internal affairs of conflict-shattered states. The ease with which Western powers would interfere in the internal affairs of sovereign states is perceive as ushering in of post-Westphalian regime (Thiessen, 2011; Tutuianu, 2013). The Westphalian regime that guided inter-state relations for several hundreds of years was abrogated (Bendana, 2006). Secondly, many states in the developing world entered a period of fragility, weakness, crisis and collapse, leading to failure to meet their basic responsibilities and functions. These states not only failed to provide society with peace, security and development, but also are perceived to pose a danger to society and the wider world. This drove to the rush of fixing failed states (Campbell et al., 2011). In combination, the two factors spurred Western powers to intervene, reconstruct and reconfigure the failed states in their own image, to the extent of engineering their collapse (Bendana, 2006) — as in the case of Libya (Campbell, 2013). A growing consensus is 'State-building seems to become a matter of introducing Western norms of liberal, market-oriented governance' (Bendana, 2006). Critics, however, note reconstruction and reconfiguration of states could not be realized through subscribing Western models, mechanisms, approaches, strategies and methodologies.

As noted above, the neoliberal interventionist SB is marked by short-term technical, administrative, foreign-expertbased management, quick fixes, and elitist and top-down approaches (Thiessen 2011; Jackson, 2018). The dominance of the neoliberal state narrative, which 'collapses the notion of freedom into freedom for economic elites' (Thompson 2005) offers the foundation for the triumph of global neoliberalism. In the technical neoliberal understanding, SB is reduced to good governance, which provides technical solutions to political problems (Bendana, 2006). Good governance is certainly important, yet it is reductionist. Governance concern administering, not government or state. Good administration could not substitute SB. SB addresses institution building as well as distribution of power and concerns social contract between state and society. These attributes are the very essence of state crisis that drive conflicts.

State decentralization is cornerstone of neoliberalism, thus, concentration of power at the centre is bad while power devolution to regions is good. Derivative of the ideological conception of the post-nation state is neoliberalism's conviction of an alternative model to SB pivoted around a decentralized and weak states, many of its functions taken over by non-state actors that include IMF, WB, CS, donors, NGOs and other social groups. Functional democratic institutions (neoliberal), rule of law, market economy and property rights are principles that guide a truncated SB. These values benefit transnational corporates in cohort with national elites that predate on privatization, foreign direct investment, deregulation and liberalization of the monetary system. The demand of creation of a conducive environment for international capital undermines the state, since it prevents the state from being able to deliver basic societal provisions, which is a vital condition for social contract and thereby state legitimacy. This political economy of SB explains fragility. Bendana (2006) explains, 'In truth, under neoliberalism, state-building becomes state-dismantling as power is turned over to transnational corporations and to the un-elected bureaucrats of the global institutions such as IMF, World Bank and WTO - a process of national and State disempowerment.' 
Evidently, post-conflict neoliberal interventionist SB is marked by deficiency of popular legitimacy. Brahimi (2007) notes: 'In Iraq, the institutions created by invaders and the Iraqis drafted to serve under occupation never acquired any legitimacy or credibility in the eyes of the people of Iraq'. The methodology of installing selected local forces for the purpose of post-conflict SB by external intervention usually lack any mandate from society. Somali federal constitution, institutions and government imposed by external actors never garnered popular legitimacy. The external imposition of institutions and actors alienate many communities and stakeholders who are not on friendly terms with external actors. In addition, external actors dictate who are to participate and who are not. Thus, the Taliban (Afghanistan), Sunni (Iraq), Al-Shabaab (Somalia) were excluded from the SB processes on the instructions of external actors. This exclusionary measure irrefutably perpetuates state crisis. Iraq is still in mess seventeen years after the demise of Saddam Hussein. In addition, the presence of external military forces in support of one side of the conflict-Americans (Iraq), Americans and NATO (Afghanistan), Ethiopians and Kenyans (Somalia), NATO (in support of rebels in Libya) - undermine functional and domestic SB process. The DRC is a good example of the presence of external military forces (Eriksen, 2009).

The cohabitation of external actors and predatory elite renders neoliberal SB precarious. The cohabitation is driven by their shared interest in excluding "non-friendly" groups and rival elites-something that only cements the precariousness of SB. The political calculation of expediency thus renders the neoliberal-oriented SB process precarious, conflict prone, exclusionary, unrepresentative, unstable and unsustainable.

'Neoliberalism has undermined democratization through the imposition from above of a procedural rather than substantive democracy. Moreover, by redefining the structures of governance, neoliberalization fragments society and alienates people's participation, running against genuine participatory democracy' (Wiegratz et al., 2018). Rather than constructing a viable democratic state, neoliberalism ends up establishing an addendum to the neoliberal world state system. Such a state is completely uprooted from its societal setting, the consequence being further cleavages, inequalities, tensions and conflicts in society. Some call this type of state Westphalian state (Araoye, 2014) or de jure state. Instead of generating peace, stability, harmony, unity and development, interventionist neoliberal SB thus fosters further state fragility, conflict, global tensions and instability.

\section{Popular Progressive Peacebuilding and State Building}

The popular progressive model of PBSB deals with the fundamentals of societal construction, in technical parlance nation and state formation. This section analyses PBSB as predicated in the popular progressive model. We begin with brief exposition of conception.

The connotation of 'popular' denotes its people-centered nature, unlike the elitist approach of neoliberalism.

'Popular invites active, conscious and decisive participation, ownership, setting of agenda and agency of common people. The concept of 'progressive' indicates the long-term, continuous, past-present-future oriented nature of PBSB. Moreover, it is an indication of the profound nature of PBSB that concerns the basic and fundamental issues of nation and state formation that is societal construction (Bereketeab 2020).

Johan Galtung, in his 1964 seminal work, draws a distinction between positive and negative peace. This has dominated the discourse on peace ever since (Grewal, 2003). Galtung expounds, 'there are two aspects of peace as conceived of here: negative peace which is the absence of violence, absence of war - and positive peace which is the integration of human society' (Galtung 1964: 2, italics in original). The concept of positive peace involves personal and structural dimensions. Personal peace concerns direct act of violence, while structural peace explicates indirect acts of violence. Therefore, the taxonomy of personal-structural and direct-indirect, or personal-direct and structural-indirect (Galtung, 1969).

Galtung's positive peace - perceived as the integration of society—is closer to the popular progressive model. A testimony of this is the connection between positive peace as social justice. Understanding social justice as the absence of social inequality and construction of an egalitarian society promotes a peaceful society. The development of an egalitarian society depends on the eradication of (or decrease in) structural violence. Galtung notes:

whereas the absence of structural violence is what we have referred to as social justice, which is a positively defined condition (egalitarian distribution of power and resources). Thus peace conceived this way is not only a matter of control and reduction of the overt use of violence, but of what we have elsewhere referred to as 'vertical development' (Galtung, 1969).

The vertical development constitutes central point in Galtung's understanding of positive peace. Positive peace is associated with development. He is of the view, without genuine development there would not be positive peace, thus, Galtung writes, 
peace research defined as research into the conditions—-past, present and future — of realizing peace, will be equally intimately connected with conflict research and development research; the former often more relevant for negative peace and the latter more relevant for positive peace, but with highly important overlap' (Galtung 1969).

Development is intimately associated with positive peace. Socio-economic development leading to abundance, and driven by equitable distribution, engenders egalitarianism and produces a peaceful society. This conception follows the tradition of classical economic liberalism and development sociology. The treatise on the wealth of nations (Adam Smith), for instance, envisaged that the accumulation of wealth, complemented by reasonably equitable distribution, would curtail class warfare and thereby lead to the pacification of society and the emergence of the welfare state. Development is a long process, as peacebuilding is. The accumulation of incremental economic wealth over prolonged timespan, dispersed among and benefiting citizens upholds the conditions for positive peace, thus the peacebuildingdevelopment nexus.

The foundations of popular progressive PB rests on holistic, national, regional, local ownership, indigenous institutions, authorities and mechanisms; inclusive bottom-up and top-down strategies (cf. Richmond 2011; Lederach 1997; Mac Ginty 2008). The fundamental difference between the popular progressive model and reformist (neo)liberal peace, concerning top-down strategy, the former pertains top-down of the national state. In addition, popular progressive PB concern local ownership of the agenda, process and solutions; long-term institution-building; complex negotiations, bargaining, compromise, reconciliation, participation, transformation; domestic process, home grown, no winner or loser outcome oriented, value systems and ethos. All this could only be achieved within the national space (among stakeholders), external intervention would only disturb national balance. According to Albert (2008), peacebuilding in Africa is influenced by 'commitment to cultural values, beliefs and norms of the people on the one hand and role expectation on the other'. This arguably confers legitimacy on the process (Jackson and Rosberg, 1984), which is an important condition for PB. Legitimacy derives from people owning and participating in values and norms that they recognize and revere, and benefits they gain. Societal construction presupposes cultivation of citizenry in and around idiosyncratic national values and norms. From a constructivist perspective, it involves molding the citizenry along the sociological process and mechanism of socialization, internalization and externalization. The significance of this becomes clear in a societal setting of poly-ethnic, poly-glottic and poly-religious, in which the norms and values molding the citizenry have to reflect plurality. The popular progressive model explains the importance of constructing national norms and values necessary for sustainable and functional PB. Accentuating the significance of socialization of individuals in a specific cultural setting, and determinacy of knowledge, values and norms of that setting, Tanabe (2017) notes, 'meaning of conflict, causes of conflict, meaning of peace, approaches to conflict resolution would be understood in different ways according to each culture'.

PB in this perspective is exclusively domestic or home-grown (cf. Paffenholz, 2015). The role of external involvement is to boost the domestic. The opposite of neoliberal is popular progressive PB. Interventionist policies lead to state fragility, failure and collapse. The popular progressive strikes balance between the divide of elite-population, statesociety; neoliberal interventionism promotes coalition of external actors and national elites. Popular progressive PB underscores the conception that 'actors are shaped by the socio-cultural milieu in which they live' (Conteh-Morgan 2004). Accordingly, it is culture and context driven. Proper comprehension of coded and decoded communication; verbal, facial and symbolic signals, demands cultural proficiency of in-depth Verstehen (interpretation), explanation and analysis - which can only be attained in hailing from the common sociocultural womb.

Popular progressive PB that follow bloody war should concern itself with society-building. Society-building involves restoring destroyed values, norms, institutions, structures and relations (Curtis 2012). It aims at restoration of societal equilibrium builds on societal morality, values, norms and ethics. Concomitant consequences of war entail destruction of morality, values, institutions and trust - even the loss of humanity, as people in wartime may exhibit brutal cruelty against their fellow human beings (Mamdani, 2009); therefore, the principal post-war PB responsibility is to restore the missing balance and equilibrium. Society-building could not lean on borrowed values and norms. The state of anomaly caused by war must be replaced by a state of normality; only then can sustainable and functional PB be ensured (Tom, 2017). Grassroots-based PB would revitalize societal structures, norms and values that are communal, collectivist, solidarist and empathic (Conteh-Morgan 2004; Gawerc 2006).

'Among African societies, symbols and rituals are key to an effective and permanent peace-building/reconstruction process' (Conteh-Morgan 2004). The hallmarks of popular progressive PB are deliberations and protracted discussions that lead to consensus among all citizens. Peace derives from the moral authority and wisdom of elders, whose guidance, oversight, decisions and leadership_-backed up by tried-and-tested praxis and ethos—are accepted and followed 
(Bereketeab, 2012). These moral fabric glue together citizens. Mediations and verdicts handed down by elders are binding and implemented to the full, although not everyone might agree with them. The reason they are accepted and obeyed is that they strive to restore social cohesion, harmony and equilibrium. Guilt is not an individual act, but is rather collective; and punishment and reward is collective act of restorative (Tom, 2017). This is truly so because African societies are socio-centric, unlike Western which are egocentric.

This, of course, does not minimize the weaknesses the elders, chiefs or tradition display. These institutions are fraught with shortcomings. The shortcomings however, belong to society that endow them familiarity, predictability and consistency that eases dealing with them. The significance of the institutions is they serve as repository of the past, norms, values and ethos that is lost on the young generation and could serve to restore balance and equilibrium thereby generating harmony, compromises and consensus.

The popular progressive model concerns restorative, rather than retributive PB. Accordingly, cultural resources of peace-making play significant role (Conteh-Morgan, 2004). Community networks, familial ties, dignity, integrity, trust and respect engender cohesion. These attributes contribute to the enhancement of conflict mediation and ensure that people abide by the verdicts handed down by mediators. The mediators and the mediated are expected to exhibit impeccable social and moral integrity; otherwise, they lose face in the community. The wisdom and the respect they command in the community render elders the best possible institution to mediate, oversee, render adjudication and guarantee decisions are implemented and heeded. The fact that the institution of elders is equipped with only moral authority, integrity, selflessness and virtue secures obedience and respect (Bereketeab, 2012).

Precolonial Africa, with degree of variation, exercised a governance system where village community would gather together under a tree under the aegis of elders, chief, council and deliberate on issues that concern them, an exercise of direct democracy, and adjudicate through democratic consensus. Conspicuously, the village council excluded certain groups, but the democratic nature of adjudication overweighed the exclusion. The power of chiefs was checked by popular consent.

consensus over substantive decisions was a central feature in most traditional African political system allowing rulers to exercise power and authority via some form of consultation with the people. As Fortes and Evans-

Pritchard point out, the 'structure of African State implies that kings and chiefs ruled by consent. A ruler's

subjects are as fully aware of the duties he owes to them as they are of duties they owe to him, and are able to exert pressure to make him discharge the duties" (Tom, 2017).

Colonialism eroded this consensus based governance system. The post-colonial Africa is constituted of two asymmetrically related spheres: urban and rural. The urban sphere, representing colonial heritage, subordinated the rural sphere, the indigenous heritage, constituting source of constant conflicts and tensions. This makes it imperative striking balance between them. Botswana and Somaliland are praised for striking balance. Both countries have done well in peace-building, stability, development and democratization (Peters, 1994; Samatar, 1997; Lewis, 2008).

In the African context and reality neoliberal approach to PB is heavily criticized. The neoliberal [liberal] PB model 'may be socially atomizing, hegemonic and lead to the valorization of a predatory state elite who gain easy access to an international economic and political cartography' (Richmond, quoted in Curtis, 2012). Neoliberal PB runs counter to the aggregating, egalitarian and collective African values and norms (Ake, 2000). These are values and norms that enhance functional and sustainable $\mathrm{PB}$, and which communities attain through continuous meetings, until they iron out their differences. The mechanism is whole villages would sit under trees for weeks on end to reach consensus.

As state centered, neoliberal PB operates at global and national state levels, and thus is elitist and minoritarian. It excludes the sub-national, the marginalized, the peripheries, the indigenous, the traditional and the cultural context of common people, therefore, fails to achieve lasting peace. Conversely, popular progressive is people centered, widely inclusive, and astride social ladders necessary for success. The concern of the popular progressive is societal construction that encompass citizens. It is a complex, protracted and sensitive political process, at the same time functional and sustainable (Bereketeab, 2021).

\subsection{Popular Progressive State Building}

The quest for independence and demise of colonialism was a popular African emancipatory demand. Arguably, it was to pave the way for popular progressive SB in post-colonial Africa. That in turn would remedy the maladies of colonial SB that became source of conflict, insecurity and state crisis in post-colonial Africa. The first remedial step concerned reconfiguration that deconstructs colonial legacies and reconstruct the newly emancipated societies. This is captured aptly in, 'THE DREAMS OF INDEPENDENCE were scintillating. The young and ambitious generation of founding 
fathers articulated visions of negritude, African socialism, and pan-Africanism, all of which pointed from an oppressed past to a glorious future' (Christensen and Laitin, 2019 emphasis in original). This was the epistemic and philosophical principle that guided the pioneer post-colonial leaders, who dreamed of restoring the dignity, integrity, virtue, rights and development of the people who just threw the yoke of servitude. The SB project, whose foundation is African values, norms, culture, civilization, institutions, moral and ethos would negate and uproot elements colonialism grafted onto the African socio-political body. Accentuating this Nkrumah advised: 'Seek ye first the political kingdom and all else shall be added unto you' (Biney, 2011). Capturing the political kingdom, presumably, would open to a bright future. The optimism was boosted by modernization theory that jubilantly predicted successful post-colonial SB.

In the new reality, SB - a political act par excellence - was considered an urgent and important task in tackling the pathologies devastating Africa. The principal responsibility the pioneer nationalist leaders took upon themselves was two-pronged: deconstruction and construction. Deconstruction was concerned with dismantling structures, institutions, relations, etc. inherited from colonialism. Construction involved building new structures, institutions, relations, etc. Regrettably, many of the colonial structures, institutions, mechanisms, etc. were reproduced (First, 1983; Ake, 2000; Tom, 2017), even though the nationalist leaders' intentions were different (Mamdani, 2017).

The reconstruction of African states, however, went amiss due to internal and external factors. The process was mishandled by internal actors who deviated from the dreams, visions and idealism they initially upheld (Ake, 2000). Consequently, nightmare of identity conflicts, civil wars, military takeovers, one-party rule, poor governance, poverty, underdevelopment, etc. reigned in lieu of optimism (Christensen and Laitin, 2019). Equally, blatant external intervention plagued the continent. This expressed in the form of neo-colonialism and the Cold War, followed by the war on terror and the scramble for resources (Schmidt, 2013; Yordanov, 2017; Tom, 2017). Nkrumah (1970) wrote about neo-colonialism: 'The essence of neo-colonialism is that the State which is subject to it is, in theory, independent and has all the outward trapping of international sovereignty. In reality its economic system and thus its political is directed from outside.' Consequently, the political economy of post-colonial SB encountered serious challenges. The national process was not given enough time and opportunity to heal the wounds inflicted by colonialism, but also was subjected to fresh new wounds.

In the popular progressive model, PBSB are intimately connected, as well as presuppose one another. SB, as a presupposition to $\mathrm{PB}$, may entail broader and longer duration. The state, as both war-maker and peace-maker determines peacebuilding:

State-building in a strict sense is about creating the Weberian monopoly of legitimate violence over a defined territory, and therefore has at its core the concentration of the means of coercion in practical terms, armies and police - under the control of the central political authority. Both the liberal rule of law and democracy, by contrast involve limiting the central state's authority to coerce, the first by putting it under a set of transparent and universal rules, the second by ensuring that the exercise of power reflects the popular will (Fukuyama, 2007).

The evolution of monopoly of legitimate violence is an indication of pacification of society. The state as war-maker, as well as peace-maker, is awarded the sole responsibility of the usage of the means of violence to employ it in PB. SB is institution-building - and building institutions takes time. Institutions need routinization, bureaucratization, predictability and dependability. This means, they need to develop into culture where citizens would be able to recognize them easily, as well as own them, respect and be guided by them. For this to happen, the institutions need to reflect and be the repository for local norms, values, belief systems, social and cultural structures. They should celebrate local heroes, sagas, shrines, valleys, mountains, seas, skies, etc. They should reflect and represent mundane life of citizens.

The popular progressive SB is distinguished by two defining characteristics. The first characteristics, SB, by its very nature is a domestic process. As such, involves negotiations, bargains, compromises, conciliations, dialogue, participation, etc. of all societal stakeholders. These stakeholders could represent societal strata classes, social groups, gender, ethnicity, religions, generations, regions, mode of life. Inclusive, representative mechanism, in pluralistic societies, could achieve a functional, sustainable and democratic SB. The second characteristics, SB, is political by its nature. Democratic SB that fails to pay attention to societal setting is doomed to fail. SB, in the popular progressive model, strives to strike balance between the two publics produced by colonialism and that defines post-colonial Africa.

Another characteristics of popular progressive SB is combination of bottom-up and top-down methodological strategy. This strategy bridges the binary created by colonialism. Post-colonial Africa consists of what Ekeh (1975) call two publics and Mamadani (2017) designated despotic decentralization. The two spheres are the urban and rural. The central objective of the popular progressive model is to reconcile the two spheres. The top-down (national level), caters 
the urban sphere, while bottom-up (local-community level) caters the rural sphere. The two are brought together in the popular progressive model. The fragility, weakness, collapse, crisis of the state stems from the absence of reconciliation of the two. The urban, representing the state remains in suspension from the rural, representing society. A functional representative state depends on penetrative engagement of the two. Nevertheless, it is of great significance to take note of the complexity of the local level. The local, in our perspective, deals with multi-ethnic, multi-lingual, multi-religious, multi-cultural societal setting that demand a careful consideration. To surmise a successful SB should be based on inclusion, participation, recognition and acceptance, compromises of multiple national actors.

\section{State Emancipation and Societal Pacification}

Two notions firmly buttress PBSB. These are state emancipation and societal pacification. These notions are related to the evolution of modern state. The evolution and maturity of the modern state is thus a constitutive requisite for state emancipation and societal pacification (Chabal and Daloz 1999; Young 1994). The dialectical relationship between the emergence of a modern state and its emancipation and societal pacification form the theoretical and empirical frame of analysis and understanding of PB and SB in the popular progressive model.

Emancipation as a constitutive of modern state represents a development of three interrelated qualities: (i) autonomy of the state, (ii) a state that stands above societal groups, (iii) the establishment of state hegemony over society (Bereketeab 2011, 2021; Chabal and Daloz 1999; Young 1994). State autonomy stands for independence of the state where it is able to exercise legitimate authority and control over society. This should occur without interference of other societal groups. As an institution, the state should emerge as autonomous organ that stand above and equally represents all societal groups. Without that autonomy, the state would not be able to exercise legitimate authority, an authority that presupposes voluntary acceptance by citizens. State hegemony over society, principally, refers to the monopoly of the means of violence. A state that shares the means of violence with other societal groups would not be perceived as hegemon. This way the state commands authoritative and legitimate power over societal groups. The significance of this development is that centrifugal forces are tamed and domesticated, thus, they are not in a position to threaten, through coercive means, the state in exercising hegemonic power. Most importantly, they are not capable of mobilizing and organizing sections of society for the primary purpose of undermining the powers of the state. This is of crucial importance in polyethnic, polyglottic and polylingual societal setting. The reality is however, many states in Africa, at one or another time, shared the means of violence with competing armed groups where the armed groups control a big part of the country. This has great significance to SBPB.

The other dimension is pacification of society. Pacification is commonly understood as a situation of peacefulness, mode of life in which amicable and peaceful means and instruments become the sole manner of resolving conflicts. It is a life characterized by peace, harmony and equilibrium (Bereketeab, 2021). The pacification of society entails two dimensions: internal and external. In the internal dimension, the most salient condition of the evolution of the state refers to the domination of the state where the submission of society is a necessary prerequisite. The variables of domination and submission, as voluntary politico-cultural and historical expressions of an evolved modern state, have to be embedded in emergent national institutions and structures, in order to ensure their sustainability. The development of such state institutions and structures, coupled with the disarming of centrifugal societal forces, produces a mature state. This state lives in peace and harmony with society. The history of ideas treats the emergence of the state as a fundamental product of the process of protracted pacification, where the State of Nature is replaced by the state of culture, pursuant to the massive material and cultural transformation.

The external dimension of pacification relates to ensuring territorial integrity, sovereignty, security and good international relations reminiscent of the Westphalian state (Osiander, 2001; Evans and Newnham, 1990; Morgenthau, 1985; Coggins, 2014). The Westphalia Treaty was perceived to generate societal pacification. This is translated to mean contributing to and living in a neighborhood where amicable peace prevails. The amicability is also a function of a broader internalization of pacification that governs inter-state relations. This produces procedures and norms that render inter-state relations predictability, stability, normalcy and rule-driven game. The contemporary post-Cold Warwhich some term post-Westphalian (Newman et al., 2009; Kreuder-Sonnen and Zang1, 2014)—neoliberal ideologydriven campaign has disrupted the status quo in international relations, leading to serious conflicts and instabilities all over the world. The neoliberal ideological strategy to mobilize non-state actors, which involves armed opposition, to counter-balance the state is a clear measure of undermining societal pacification. Forgetting their history of societal pacification, Western powers engage in abetting and support centrifugal forces in the aim of regime change. 


\section{Conclusion}

This paper set out to analyze conceptualization of PBSB in conflict-shattered societies. It examined two theoretical and conceptual models. These are neoliberal and its alternative popular progressive. The defining feature of neoliberal PBSB are duly identified as primarily technical, administrative, short-term, top-down, external imposition of expertise, knowledge, institutions, norms and values. It is an attempt of reconstruction of conflict-shattered societies along Western mould. Advocates of neoliberal rarely provide precise definition. The alternative popular progressive concerns profoundly about societal construction, nation and state formation. It is based on protracted negotiations, bargains, dialogue, comprises, reconciliations, among all national stakeholders. Promotes indigenous institutions, structures, authorities, mechanisms, bottom-up and top-down strategies. It is long-term, embraces past-present-future trajectory, address root causes of conflicts. It is based on the perception PBSB is profoundly domestic and political that relate to accountability and legitimacy.

Proponents of neoliberal, in a decontextualized, ahistorical and hegemonic manner, elevate PBSB to universalism where it is taken for granted. Neoliberalism is based on fallacious assumptions. Some of the assumptions are: (i) liberal/ neoliberal peace have universal validity, applicable in every situation (forgetting its specific ontological and epistemological origin), (ii) interveners have the right to build peace and state for war-shattered societies, (iii) failures are shunned, need adjustment, instead of fundamental reorientation, (iv) the recipient people want interveners to build house for them.

\section{References}

Ake, Claude. (2000). The Feasibility of Democracy in Africa. Dakar: Council for the Development of Social Science Research in Africa (CODESRIA).

Albert, Isaac, O. (2008). 'Understanding Peace in Africa. in David J. Francis (ed.), Peace and Conflict in Africa. London: Zed Books.

Araoye, Ademola. (2014). Sources of Conflict in the Post Colonial African State. Trenton, London, Cape Town, Nairobi, Addis Ababa, Asmara, Ibadan, New Delhi: African World Press.

Barnett, Michael. (2006). Building a Republican Peace: Stabilizing States after War. International Security, 30(4), 87-112.

Bauman, Zygmunt. (2000). Modernity and the Holocaust. Ithaca, New York: Cornel University Press.

Bayarat, Jean-Francois. (1993). The State in Africa: The Politics of the Belly. New York: Longman.

Bendana, Alejandro. (2006). Peace-building and Neoliberalism: Will Foreign Dictated State-Building Prevail?. Journal für Entwicklungspolitik, (3) 35-54.

Bereketeab, Redie. (2021). Peacebuilding in Africa: Popular Progressive versus Neoliberal Peacebuilding. in Victor Adetula, Redie Bereketeab and Cyril Obi (eds.), Regional Economic Communities and Peacebuilding in Africa: Lessons from ECOWAS and IGAD. London New York: Routledge.

Bereketeab, Redie. (2020). Alternatives to Neoliberal Peacebuilding and Statebuilding in Africa. London: Routledge.

Bereketeab, Redie. (2012). Re-examining Local Governance in Eritrea: The Redrawing of Administration Regions. African and Asian Studies, 11(1-2), 1-29.

Bereketeab, Redie. (2011). Rethinking State Building in the Horn of Africa: Challenges of Striking a Balance Between Traditional and Modern Institutions. African Studies, 70(3), 376-392.

Biney, Ama. (2011). The Political and Social Thought of Kwame Nkrumah. New York: Palgrave Macmillan.

Brahimi, Lakhdar. (2007). State Building in Crisis and Post-Conflict Countries. presented at 7th Global Forum on Reinventing Government, Building Trust in Government, June 26-29, Vienna, Austria.

Bratton, Michael and De Walle, Nicolas. (1997). Democratic Experiment in Africa: Regime Transition in Comparative Perspective. Cambridge: Cambridge University Press.

Carmody, Padraig and Owusu, Francis. (2018). Neoliberalism, Urbanization and Change in Africa, in Nana Poku and Jim Whitman (Eds.), Africa under Neoliberalism, London and New York, 61-75.

Call, Charles, T. (2008a). Ending Wars, Building States. in Charles T. Call and Vanessa Wyeth (eds.), Building States to Build Peace. Boulder, CO, and London: Lynne Rienner Publishers. 
Call, Charles, T. and Wyeth, Vanessa (Eds.) (2008). Building States to Build Peace. Boulder, CO, and London: Lynne Rienner Publishers.

Campbell, Susasnna., Chandler, David. and Sabaratnam, Meera. (Eds.) (2011). A Liberal Peace? The Problems and Practices of Peacebuilding. London and New York: Zed Books.

Campbell, Horace. (2013). Global NATO and the Catastrophic Failure in Libya: Lessons for Africa in the Forging of African Unity. New York: Monthly Review Press.

Chabal, Patrick. and Daloz, Jean-Pascal. (1999). Africa Works: Disorder as Political Instrument. Oxford, Bloomington and Indianapolis, IN: James Currey and Indiana University Press.

Chandler, David. (2013). Peacebuilding and the Politics of Non-Linearity: Rethinking "Hidden" Agency and "Resistance". Peacebuilding, 1(1), 17-32.

Christensen, Darin. and Laitin, David, D. (2019). African States Since Independence: Order, Development, and Democracy. New Haven, CT, and London: Yale University Press.

Coggins, Bridget. (2014). Power Politics and State Formation in the Twentieth Century: The Dynamics of Recognition. New York: Cambridge University Press.

Conteh-Morgan, Earl. (2004). Peace-building and Human Security: A Constructivist Perspective. in Hideaki Shinoda and Ho-Won Jeong, Conflict and Human Security: A Research for New Approaches of Peace-building, IPSHU English Research Report Series No. 19. Hiroshima: Hiroshima University.

Curtis, Devon. (2012). The Contested Politics of Peace-building in Africa. in Devon Curtis and Gwinyayi Dzinesa (eds), Peace-building, Power, and Politics in Africa. Athens, OH: Ohio University Press.

Curtis, Devon and Dzinesa, Gwinyayi (Eds.) (2012). Peace-Building, Power, and Politics in Africa. Athens: Ohio University Press.

Dahrendorf, Ralf. (1990). Reflection on the Revolution in Europe. London: Chatto and Windus.

Ekeh, Peter, P. (1975). Colonialism and the Two Publics in Africa: A Theoretical Statement. Comparative Studies in Society and History, 17(1), 91-112.

Englebert, Pierre. (2000). State Legitimacy and Development in Africa. Boulder, CO: Lynne Rienner Publishers.

Eriksen, Stein, Sundstol. (2009). The Liberal Peace is Neither: Peace-Building, State Building and the Reproduction of Conflict in the Democratic Republic of Congo. International Peacekeeping, 16(5), 666.

Evans, Graham. and Newnham, Jeffrey. (1990). The Dictionary of Wold Politics: A Reference Guide to Concepts, Ideas, and Institutions. Hemel Hempstead: Harvester Wheatsheaf.

Fanthrope, Richard. (2005). On the Limits of Liberal Peace: Chiefs and Democratic Decentralization in Post-War Sierra Leone, African Affairs, 105(418), 27-49.

First, Ruth. (1983). Colonialism and the Formation of African States. in David Held et al. (Eds), States and Societies. Oxford and Cambridge, MA: Blackwell.

Fukuyama, Francis. (2007). Liberalism Versus State-Building. Journal of Democracy, 18(3), 10-13.

Fukuyama, Francis. (1992). The End of History and the Last Man. New York and Ontario: The Free Press.

Galtung, Johan. (1969). Violence, Peace, and Peace Research. Journal of Peace Research, 6(3), 167-191.

Galtung, Johan, (1964). An Editorial. Journal of Peace Research, 1(1), 1-4.

Gawerc, Michelle, I. (2006). Peace-Building: Theoretical and Concrete Perspectives. Peace and Change, 31(4), 435-478.

Grewal, Baljit, Singh. (2003). Johan Galtung: Positive and Negative Peace. School of Social Science: Auckland University of Technology.

Grävingholt, Järn. et al. (2009). Policy Brief: Concepts of Peace-Building and State Building - How Compatible are They?. German Development Institute, 11 March.

Hameiri, Shahar. (2014). The Crisis of Liberal Peacebuilding and the Future of Statebuilding. International Politics, 51(3), 316-333.

Harrison, Graham. (2010). Neoliberal Africa: The Impact of Global Social Engineering. London and New York: Zed Books. 
Herbst, Jeffrey. (2000). States and Power in Africa: Comparative Lessons in Authority and Control. Princeton, NJ: Princeton University Press.

Huntington, Samuel, P. (1996). Clash of Civilisations and the Remaking of World Order. New York: Simon and Schuster. Hyden, Goran. (2013). African Politics in Comparative Perspective, 2nd ed. New York: Cambridge University Press.

Jackson, Richard. (2018). Post-Liberal Peace-Building and the Pacifist State. Peacebuilding, 6(1), 1-16.

Jackson, Robert. and Rosberg, Carl, G. (1984). Popular Legitimacy in African Multi-Ethnic States. Journal of Modern African Studies, 22(2), 177-198.

Kamrava, Mehran. (2000). Politics and Society in the Developing World. London and New York: Routledge.

Knapp, Andrew. and Footitt, Hilary. (2013). Introduction. in Andrew Knapp and Hilary Footitt (eds.), Liberal Democracies at War: Conflict and Representation. London, New Delhi, New York, Sydney: Bloomsbury.

Kreuder-Sonnen., Christian. and Zangl, Bernhard. (2014). Which Post-Westphalia? International Organizations Between Constitutionalism and Authoritarianism. European Journal of International Relations, 2(3), 568-594.

Lazzarato, Mauricio. (2015). Neoliberalism, the Financial Crisis and the End of the Liberal State. Theory, Culture and Society, 37(7-8) 67-83.

Lederach, John, Paul. (1997). Building Peace: Sustainable Reconciliation in Divided Societies. Washington DC: United States Institute of Peace.

Lewis, Ioan. (2008). Understanding Somalia and Somaliland. London: Hurst \& Company.

Maiese, Michelle. (2003). Peacebuilding. https://www.beyondintractability.org/essay/peacebuilding. Accessed on June 27,2016.

Mamdani, Mahmood. (2017). Citizen and Subject: Contemporary Africa and the Legacy of Late Colonialism, with a New Preface. Johannesburg and Kampala: Wits University Press and Makerere Institute of Social Research.

Mamdani, Mahmood. (2009). Saviors and Survivors: Darfur, Politics, and the War on Terror. New York, Toronto: Pantheon Books.

Mamdani, Mahmood. (2017). Citizen and Subject: Contemporary Africa and the Legacy of Late Colonialism, with a New Preface, Johannesburg and Kampala: Wits University Press and Makerere Institute of Social Research.

Mac Ginty, Roger. (2008). Indigenous Peace-Making Versus the Liberal Peace', Cooperation and Conflict. Journal of the Nordic International Studies Association, 43(2), 139-163.

Mitchell, William. and Fazi, Thomas. (2017). Reclaiming the State: A Progressive Vision of Sovereignty for a PostNeoliberal World. London: Pluto Press.

Morgenthau, Hans, J. (1985). Politics among Nations: The Struggle for Power and Peace, 6th ed. Revised and edited by Kenneth W. Thompson. New York: McGraw-Hill.

Newman, Edward., Paris, Roland. and Richmond, Oliver, P. (2009). Introduction. in Edward Newman, Roland Paris and Oliver P. Richmond (eds), New Perspectives on Liberal Peace-Building. Tokyo and New York: United Nations University Press.

Ngongo, Francis, Kapalo. (2012). Impasse of Post-Conflict Reconstruction: Economic Growth vs. Governance in Angola. Houston: Strategic Book Publishing and Rights Co.

Nkrumah, Kwame. (1970). Neo-Colonialism: The Last Stage of Imperialism. London: PANAF.

Oda, Hiroshi. (2007). Peace-Building from Below: Theoretical and Methodological Considerations toward an Anthropological Study on Peace. Journal of the Graduate School of Letters, 2, 1-16.

Omach, Paul. (2012). The Limits of Disarmament, Demobilisation and Reintegration. in Devon Curtis and Gwinyayi Dzinesa (eds), Peace-building, Power, and Politics in Africa. Athens, OH: Ohio University Press.

Osiander, Andreas. (2001). Sovereignty, International Relations, and the Westphalian Myth. International Organization, $55(2), 251-287$.

Paffenholz, Thania. (2015). Unpacking the Local Turn in Peace-Building: A Critical Assessment Towards an Agenda for Future Research. Third World Quarterly, 36(5), 857-874.

Poggi, Gianfranco. (1978). The Development of the Modern State. London: Hutchinson.

Paris, Roland. (2010). Saving Liberal Peace-Building. Review of International Studies, 36, 337-365.

Paris, Roland. (2002). International Peace-Building and the Mission Civilisatrice. Review of International Studies, 28(4), 637-656. 
Peters, Pauline. (1994). Dividing the Commons: Politics, Policy, and Culture in Botswana. Charlottesville, UA: Virginia University Press.

Poku, Nana. and Whitman, Jim. (Eds). (2018). Africa under Neoliberalism. London and New York: Routledge.

Reiter, Dan. and Stam, Allan, C. (2002). Democracies at War. Princeton and Oxford: Princeton University Press.

Reppell, Lisa., Rozen, Jonathan. and Carvalho, Gustavo de. (2016). Planning for Peace: Lessons from Mozambique's Peacebuilding Process. Institute for Security Studies, ISS Paper 291/June 2016.

Richmond, Oliver, P. (2013). The Legacy of State Formation Theory for Peacebuilding and Statebuilding. International Peacekeeping, 20(3), 299-315.

Richmond, Oliver, P. (2011). Critical Agency, Resistance and Post-Colonial Civil Society. Cooperation and Conflict, 46(4), 419-440.

Sabaratnam, Meera. (2011). Situated Critiques of Intervention: Mozambique and the Diverse Politics of Response. in Campbell, S. Chandler D. and Sabaratnam (Eds.), A Liberal Peace? The Problems and Practices of Peacebuilding. London: Zed Books.

Sabaratnam, Meera. (2011). The Liberal Peace? An Intellectual History of International Conflict Manegament, $1990-2010$. in Campbell, S. Chandler D. and Sabaratnam (Eds.), A Liberal Peace? The Problems and Practices of Peacebuilding. London: Zed Books.

Samatar, Abdi, Ismail. (1997). Leadership and Ethnicity in the Making of African State Models: Botswana Versus Somalia. Third World Quarterly, 18(4), 687-708.

Sandbrook, Richard. (2007). Alternatives to Neo-liberalism in the Third World. Renewal, 15(2\&3), 46-57.

Schmidt, Elizabeth. (2013). Foreign Intervention in Africa: From the Cold War to the War on Terror. Cambridge: Cambridge University Press.

Tanabe, Juichiro. (2017). Beyond Liberal Peacebuilding: A Critique of Liberal Peacebuilding and Exploring a Postmodern Post-Liberal Hybrid Model of Peacebuilding. International Relations and Diplomacy, 5(8), 447-459, Doi:10.17265/ 2328-2134/2017.08.001

Thiessen, Charles. (2011). Emancipatory Peace-Building: Critical Response to (Neo)Liberal Trends. in Thomas Matyok, Jessica Senehi and Sean Byrne (eds), Critical Issues in Peace and Conflict Studies: Theory, Practice, and Pedagogy. Lanham, MD, and Plymouth: Lexington Books.

Thompson, Michael, J. (2005). The World According to David Harvey. Democratiya, 3, 22-27.

Tom, Patrick. (2017). Liberal Peace and Post-Conflict Peace-Building in Africa. London: Palgrave Macmillan.

Tuluianu, Simona. (2013). Towards Global Justice: Sovereignty in an Interdependent World. The Hague: Asser Press.

Viterbo, Annamaria. (2018). The Role of the International Financial Institutions in Fragile and Conflict-Affected Countries. in Giovanni Cellamare and Ivan Ingravallo (Eds), Peace Maintenance in Africa: Open Legal Issues. Cham: Springer.

Wambugu, Nyambura. (2019). Post-Conflict Security in South Sudan: From Liberal Peacebuilding to Demilitarization. London, New York, Oxford, New Delhi, Sydney: I.B. Tauris.

Wiegratz, Jörg., Martiniello, Giuliano. and Greco, Elisa. (2018). Introduction: Interpreting Changes in Neoliberal Uganda. in Jörg Wiegratz, Giuliano Martiniello and Elisa Greco (eds), Uganda: The Dynamics of Neoliberal Transformation. London: Zed Books.

Yordanov, Radoslav, A. (2017). The Soviet Union and the Horn of Africa during the Cold War: Between Ideology and Pragmatism. Lanham, Boulder, New York, London: Lexington Books.

Young, Crawford. (1994). The African Colonial State in Comparative Perspective. New York and London: Yale University Press.

Zaum, Dominik. (2012). Statebuilding and Governance: The Conundrum of Legitimacy and Local Ownership. in Devon Curtis and Gwinyayi Dzinesa (eds.), Peace-building, Power, and Politics in Africa. Athens, OH: Ohio University Press.

Citethis articleas: RedieBereketeab (2021). Understanding Peacebuil ding and StateBuilding: Post-Conflict African Challenges. International J ournal of A frican Studies. 1(3), 16-30. doi: 10.51483/ IJAFRS.1.3.2021. 16-30. 